\title{
Unravelling the complexities of the first breaths of life
}

David G Tingay*1,2,3,4, Olivia Farrell ${ }^{1,2}$, Jessica Thomson ${ }^{1,2}$, Elizabeth J Perkins ${ }^{1}$, Prue M PereiraFantini $^{1,2}$, Andreas D Waldmann ${ }^{5}$, Christoph Rüegger ${ }^{4}$, Andy Adler $^{6}$, Peter G Davis ${ }^{4}$, Inéz Frerichs ${ }^{7}$

${ }^{1}$ Neonatal Research, Murdoch Children's Research Institute, Melbourne, Australia

${ }^{2}$ Department of Paediatrics, University of Melbourne, Melbourne, Australia

${ }^{3}$ Neonatology, Royal Children's Hospital, Melbourne, Australia

${ }^{4}$ Neonatal Research, The Royal Women's Hospital, Melbourne, Australia

${ }^{5}$ Department of Anesthesiology and Intensive Care Medicine, Rostock University Medical Center, Germany

${ }^{6}$ Department of Systems and Computer Engineering, Carleton University, Ottawa, Canada

${ }^{7}$ Department of Anaesthesiology and Intensive Care Medicine, University Medical Centre Schleswig-Holstein, Campus Kiel, Kiel, Germany

\section{Corresponding Author:}

A/Prof David G Tingay MB BS DCH FRACP Ph.D.

Neonatal Research

Murdoch Children's Research Institute

Royal Children's Hospital Flemington Rd.

Parkville 3052 Victoria

Australia

$+61393454023$

+6139345 5067 (fax)

Email: david.tingay@rch.org.au 
Short title: The first breaths of life

Descriptor: 14.3 Neonatal Lung Disease \& BPD

Word Count: 3500 words

Keywords: Neonate; electrical impedance tomography; birth; ventilation; aeration

This article has an online data supplement, which is accessible from this issue's table of content online at www.atsjournals.org

Author Contributions: DGT developed the concept and designed the experiment. DGT, OF, JT, EJP, CR enrolled and studied all infants. AW, IF, AA, DGT developed the image reconstruction and analysis methods used in the study. DGT, OF, JT, PP-F were involved in data analysis. DGT, PGD, IF, AA interpreted the data. DGT wrote the first draft of the manuscript and all authors contributed to redrafting the manuscript.

Financial Support: This study is supported by the Victorian Government Operational Infrastructure Support Program (Melbourne, Australia) and a grant from a National Health and Medical Research Council Centre of Research Excellence (Grant ID 1057514). DGT is supported by a National Health and Medical Research Council Clinical Career Development Fellowship (Grant ID 1053889). PGD is supported by a National Health and Medical Research Council Program Grant (Grant ID 606789). PGD is supported by a National Health and Medical Research Council Practitioner Fellowship (Grant ID 556600).

Competing Interests: AW was an employee of Swisstom AG (Landquart, Switzerland), who initially developed the EIT hardware and software systems (Swisstom was acquired by Sentec AG after the study was completed). Swisstom was not involved in study design, implementation, analysis, interpretation or reporting. IF and AW were investigators in an European Union Horizon 2020 Research and Innovation program grant to develop an infant EIT chest imaging system 
(CRADL project, Grant ID 668259). IF also reports funding from another European Union Horizon 2020 project (WELMO, Grant ID 825572) and reimbursement of soeaking fees, congress and travel costs by Dräger Medical (a company that produces a commercial EIT unit). No author received an honorarium, grant, or other form of payment to produce the manuscript. The study was not commissioned and no commercial agencies were involved in any aspect of this study. The authors have no other competing interests to declare.

Ethics Approval: The Royal Women's Hospital Human Research and Ethics Committee (\#16-33), and registered with the Australian New Zealand Clinical Trials Registry (ACTRN12618000128291).

Data Sharing: Individual participant data collected during the study, after de-identification, and study protocols and statistical analysis code are available beginning 3 months and ending 23 years following article publication to researchers who provide a methodological sound proposal, with approval by an independent review committee ("learned intermediatry") identified for purpose. Data is available for analysis to achieve aims in the approved proposal. Proposals should be directed to david.tingay@mcri.edu.au; to gain access, data requestors will need to sign a data access or material transfer agreement approved by the Murdoch Children's Research Institute. 
medRxiv preprint doi: https://doi.org/10.1101/2020.07.29.20161166; this version posted October 26, 2020. The copyright holder for this preprint

(which was not certified by peer review) is the author/funder, who has granted medRxiv a license to display the preprint in perpetuity.

All rights reserved. No reuse allowed without permission.

\section{At a Glance Commentary}

\section{Scientific Knowledge on the Subject}

Birth requires the rapid transition from a fluid-filled to aerated lung that is poorly understood. Limited human and animal studies suggest high intrathoracic pressure and flow states are required to attain functional residual capacity and support tidal ventilation.

\section{What this Study Adds to the Field}

In the first breath-by-breath imaging of the lungs of term neonates undergoing successful respiratory transition at birth we identified highly inhomogeneous, spatiotemporal aeration and ventilation patterns during. Crying at birth preserved functional residual capacity by allowing intrathoracic volume redistribution (pendelluft flow) within the lung. Newborns defend aeration from intrathoracic lung-fluid shifts at birth by innately braking expiratory flow using the glottis and diaphragm. 
medRxiv preprint doi: https://doi.org/10.1101/2020.07.29.20161166; this version posted October 26, 2020. The copyright holder for this preprint

(which was not certified by peer review) is the author/funder, who has granted medRxiv a license to display the preprint in perpetuity.

All rights reserved. No reuse allowed without permission.

\section{ABBREVIATIONS:}

$\mathrm{AU}$

Arbitrary Units

$\mathrm{CoV} \quad$ Centre of Ventilation

EIT

Electrical Impedance Tomography

FRC Functional Residual Capacity

PEF Peak Expiratory Flow

PIF Peak Inspiratory Flow

$\mathrm{SpO}_{2} \quad$ Peripheral oxygen saturation

$\tau$

Time constant (tau)

$\mathrm{Ti} \quad$ Inspiratory time

Te Expiratory time

$\begin{array}{ll}\mathrm{V}_{\mathrm{T}} & \text { Tidal Volume }\end{array}$ 
medRxiv preprint doi: https://doi.org/10.1101/2020.07.29.20161166; this version posted October 26, 2020. The copyright holder for this preprint (which was not certified by peer review) is the author/funder, who has granted medRxiv a license to display the preprint in perpetuity.

All rights reserved. No reuse allowed without permission.

\section{ABSTRACT}

Rationale: The transition to air-breathing at birth is a seminal respiratory event common to all humans, but the intrathoracic processes remain poorly understood.

Objectives: The objectives of this prospective, observational study were to describe the spatiotemporal gas flow, aeration and ventilation patterns within the lung in term neonates undergoing successful respiratory transition.

Methods: Electrical impedance tomography was used to image intrathoracic volume patterns for every breath until six minutes from birth in neonates born by elective cesearean section and not needing resuscitation. Breaths were classified by video data, and measures of lung aeration, tidal flow conditions and intrathoracic volume distribution calculated for each inflation.

Measurements and Main results: 1401 breaths from 17 neonates met all eligibility and data analysis criteria. Stable functional residual capacity was obtained by median (IQR) $43(21,77)$ breaths. Breathing patterns changed from predominantly crying $(80.9 \%$ first minute $)$ to tidal breathing $(65.3 \%$ sixth minute). From birth tidal ventilation was not uniform with the lung, favouring the right and non-dependent regions; $p<0$-001 versus left and dependent (mixed effects model). Initial crying created a unique pattern with delayed mid-expiratory gas flow associated with intrathoracic volume redistribution (pendelluft flow) within the lung. This preserved functional residual, especially within the dorsal and right regions.

Conclusions: The commencement of air-breathing at birth generates unique flow and volume states associated with marked spatiotemporal ventilation inhomogeneity not seen elsewhere in respiratory physiology. At birth neonates innately brake expiratory flow to defend functional residual capacity gains and redistribute gas to less aerated regions.

Abstract word count: 249 words 
medRxiv preprint doi: https://doi.org/10.1101/2020.07.29.20161166; this version posted October 26, 2020. The copyright holder for this preprint (which was not certified by peer review) is the author/funder, who has granted medRxiv a license to display the preprint in perpetuity.

All rights reserved. No reuse allowed without permission.

\section{INTRODUCTION}

The rapid adaptation to air-breathing at birth (aeration) is one of the most important, but least understood, physiological events in humans. Much of our understanding is inferred from preclinical studies (1-4) or invasive observational studies.(5-8) These studies suggest that creating a functional residual capacity (FRC) during the initial process of lung aeration requires first clearing the airways of fetal lung liquid using high intra-thoracic pressure gradients.(1,2,5) Subsequent tidal ventilation must prevent influx of fluid back into the alveoli during expiration.(1) Animal studies have demonstrated that these processes exhibit a high degree of spatiotemporal variability within the lung. $(2,9)$ For most newborns, fluid clearance and the transition from placenta to lung as the organ of gas exchange is achieved through the spontaneous onset of breathing. When this process fails, especially in preterm infants, death or significant morbidity may result. Due to an inability to define the processes of aeration and ventilation at birth, effective evidence-based interventions to support breathing after birth are lacking. $(10,11)$

The development of effective delivery room interventions first requires an understanding of the physiological processes defining success or failure of aeration at birth. Adapting physiological concepts from preclinical studies have limited utility as instrumentation restricts the ability to emulate respiratory mechanics and the neurological state of the breathing human infant. $(1-3,12)$ The delivery room further creates a challenging research environment, the time critical and dynamic nature of birth itself hampers physiological measurements.(13) Lung volume changes at birth have been intermittently imaged using chest radiography(14) and ultrasound(15), and pressure and flow patterns measured invasively at the mouth or pharynx.(5,16) These studies identified unique breath types associated with high intra-thoracic pressure gradients during successful respiratory transition in term infants, specifically crying and grunting. $(5,17,18)$ Importantly, these studies failed to directly define the fundamental dynamic spatiotemporal processes of aeration and subsequent ventilation within the lung. 
To address this gap in knowledge, we used electrical impedance tomography (EIT), an emerging radiation-free imaging modality.(19) EIT uses the differential electrical properties of aerated and fluid-containing tissue to measure the tidal and end-expiratory volume changes in lung regions within a transverse chest slice.(19) We adapted our EIT techniques for measuring the respiratory transition in preclinical studies.(2-4,12,20-23) This allowed non-invasive, and non-hazardous, direct imaging of the dynamic breath-to-breath regional process of aeration at birth in human infants without interfering with normal physiology or clinical care. The objective of this study was to describe the spatiotemporal respiratory patterns associated with the successful transition to airbreathing after birth in term infants. The specific aims were to 1) characterise the inspiratory and expiratory time and flow characteristics within the lung at birth, and 2) describe the resultant spatiotemporal ventilation and volume patterns by breath type and time. 
medRxiv preprint doi: https://doi.org/10.1101/2020.07.29.20161166; this version posted October 26, 2020. The copyright holder for this preprint

(which was not certified by peer review) is the author/funder, who has granted medRxiv a license to display the preprint in perpetuity.

All rights reserved. No reuse allowed without permission.

\section{METHODS}

A detailed methodology can be found in the online supplement. This prospective observational study was conducted at the Royal Women's Hospital, Melbourne, Australia.

Infants were eligible for enrolment if they were delivered by elective caesarean section via spinal anaesthesia for non-fetal reasons at $\geq 36^{+0}$ weeks gestation, and written prospective parental consent obtained. Infants were not included if placement of an EIT belt would interfere with clinical care,(24-26) or the fetus had a known congenital condition that would alter EIT interpretability. Infants who received resuscitative interventions were excluded from analysis.

\section{Measurements}

Heart rate and peripheral oxygen saturation $\left(\mathrm{SpO}_{2}\right)$ were measured with a Radical 7 pulse oximeter (Massimo Corporation, Irvine CA). Regional lung volume changes were imaged at 48 frames/s with the Pioneer EIT system using an ultrasound gel-coated NeoSensor Belt (Sentec AG, Landquart, Switzerland).(2,12,24-26) Audio and video were recorded at 30 frames/s (Logitech webcam, Lausanne, Switzerland).

\section{Delivery room protocol}

As the infant was being placed supine on the resuscitaire the NeoSensor Belt was secured (velcro tab) around the chest at nipple level (Supplementary Video 1). The pulse oximetry sensor was applied to the right hand. There was no other interference with routine clinical care. Infants were managed in a supine position in accordance with local guidelines, including timing of umbilical cord clamping. Data were only recorded during care on the resuscitaire. 
medRxiv preprint doi: https://doi.org/10.1101/2020.07.29.20161166; this version posted October 26, 2020. The copyright holder for this preprint (which was not certified by peer review) is the author/funder, who has granted medRxiv a license to display the preprint in perpetuity.

All rights reserved. No reuse allowed without permission.

\section{Data acquisition and analysis}

EIT, video, audio and pulse oximetry data were continuously recorded digitally during resuscitaire management, and timing of critical events from birth documented. $\mathrm{SpO}_{2}$ and heart rate data were reviewed for loss of signal or movement artefact. EIT data were recorded in a custom-built infant imaging package,(27) and images reconstructed post hoc $(19,28)$ using the vendor-provided human model chest atlas, with non-lung regions excluded.(2,23,24,26) Each potential tidal volume $\left(\mathrm{V}_{\mathrm{T}}\right)$ change due to breathing was identified from the global lung signal. Analysis of the EIT change associated with a breath was only performed if there was 1) video confirmation of a breath; and 2) no movement interference on the video. All included breaths were classified by the presence of an audible cry, grunt or no breathing noise (tidal breath). If audio classification was not possible the breath was excluded (Supplementary Figure 1).

For included breaths, the pre and post-breath FRC, inspiratory time (Ti), expiratory time (Te), time constant of the respiratory cycle $(\tau)$ and relative peak inspiratory (PIF) and expiratory flow (PEF) were calculated for the global signal and right, left, ventral and dorsal lung regions.(19) The shape of the impedance change during each breath was classified by an investigator (DGT) unaware of the breath type or time from birth. The centre of ventilation along the ventrodorsal $\left(\mathrm{CoV}_{\mathrm{VD}}\right)$ and rightleft $\left(\mathrm{CoV}_{\mathrm{RL}}\right)$ planes were calculated to determine spatiotemporal distribution of $\mathrm{V}_{\mathrm{T}}$ within the chest slice. $(19,29)$ The percentage of the global $\mathrm{V}_{\mathrm{T}}$ signal was calculated for the most dependent, central and non-dependent thirds of the right and left lung regions, and the percentage and location of lung regions without any $\mathrm{V}_{\mathrm{T}}$ signal.(19,24)

\section{Sample size and statistical analysis}

Based on a previous study of respiratory parameters at birth (16), a convenience sample of thirty infants was estimated to provide data for breath-by-breath classification. and analysis of 100-150 breaths/infant per 5-6 minute period in 15-20 infants. Continuous data were analysed with a mixed- 
effects linear regression model, with robust standard error and cluster analysis to adjust for multiple breaths from each infant. A p value $<0.05$ was considered statistically significant.

\section{RESULTS}

A visual abstract of the main study findings is available in Supplementary Video 2.

\section{Study population}

Thirty-three families were approached on the day of the delivery, with three declining to participate. Two studied infants received resuscitative support after birth and were excluded. Of the remaining 28 infants, EIT data were obtained in 27 infants (EIT belt incorrectly placed). Complete audio or video data were not acquired in ten infants (technical failure in delivery room, camera obstructed, excessive background noise or inability to delineate any audio/video breaths). The characteristics of the final 17 infants with matched EIT, video and audio data are described in Supplemental Table 1. All were singleton pregnancies and no mother received antenatal corticosteroids.

\section{Pulse oximetry}

A pulse oximetry signal could be acquired in 15 infants, with a median (range) of $17(3,198) \mathrm{s}$ between applying the probe and signal acquisition. The first $\mathrm{SpO}_{2}$ signal was acquired at 52 (12, 97)s, but then lost for $>10$ s at least once in ten infants. $\mathrm{SpO}_{2}$ increased with time from $53(48,72) \%$ at $60 \mathrm{~s}$ to $78(60,96) \%$ by $360 \mathrm{~s}$ ( $\mathrm{p}=0.029$; mixed-effects model, Supplementary Figure 2 ). Heart rate was stable throughout the study period $(\mathrm{p}=0.25)$.

\section{Time to image acquisition}

The median (range) time from birth to first EIT image was $36(20,62)$, with the longest periods being in the two infants born with delayed cord clamping (60 and 62s). The time between cutting of 
umbilical cord and first EIT image was $31(20,48)$ s. In all infants the time between applying the EIT belt and first images was $<12 \mathrm{~s}$, with no subsequent signal loss.

\section{Breathing patterns}

A total of 1401 inflations met the inclusion criteria (Table 1). Only 14 breaths (1\%) had audible grunting (all during periods of crying), and were included within the 787 crying breaths. Overall, crying was more prominent early in the respiratory transition, representing $80.9 \%$ of all included inflations within the first minute, then decreasing to $34.7 \%$ by the sixth minute $(\mathrm{p}<0.0001$; chisquared test for trend).

Breaths could be classified as following two distinct EIT volume patterns; 1) linear inspiratory and expiratory volume change consistent with tidal ventilation of already-aerated lungs, or 2) an expiratory phase with a distinct bifid expiratory wave and a transient increase or preservation in lung volume (Figure 1 and Supplementary Video 2). During these bifid waves there was a subtle redistribution of ventilation seen on fEIT images consistent with pendelluft flow. $70.8 \%$ of all crying breaths had a bifid wave, but only $2.5 \%$ of tidal breaths.

Ti increased over the first minutes of life for both breath types; $\mathrm{p}<0.0001$ (Figure 2A). Crying generated shorter Ti than tidal breaths in the first 60s, mean $(95 \% \mathrm{CI})$ difference $101(56,147) \mathrm{ms}$. In contrast, Te and $\tau$ were longer during crying than tidal breaths (both $\mathrm{p}<0.0001$; Figure $2 \mathrm{~B}$ and C), especially between 61-180s (Te) and after 120s $(\tau)$. Overall, Te and $\tau$ did not change significantly with time for crying or tidal breaths.

PIF was greater at all time epochs during crying compared to tidal breaths (all $\mathrm{p}<0.0001$ ). Overall, PIF increased with time for tidal breaths ( $\mathrm{p}<0.0001$; Figure 2D), but not during crying. PEF was greater during crying than tdal breaths for the first 180s (all $\mathrm{p}<0.0001$; Figure 2E), with the greatest 
difference in the first $60 \mathrm{~s}(1.4(0.9,1.8) \mathrm{AU} / \mathrm{s})$. PEF decreased with with time during crying ( $\mathrm{p}<0.0001)$, whilst tidal breaths were unchanged.

The detailed spatiotemporal behaviour of Ti, Te, $\tau$, PIF and PEF in the right, left, ventral and dorsal regions are provided in the supplemental results (Supplemental Figures 3-7). Overall, Ti , Te and $\tau$ were similar within all regions for both breath types. Crying resulted in faster PIF and PEF in the dorsal and right regions compared to ventral and left respectively. Tidal breaths resulted in less right-left and ventral-dorsal heterogeneity in PIF and PEF than crying.

\section{Functional residual capacity}

Overall, FRC increased, and was quickly established, after birth, with the maximum recorded FRC value for each infant occurring at a median (IQR) $43(21,77)$ of included breaths after birth; 67.8 $(51.9,94.5) \%$ of the analysed sequential breaths (Figure 3 and Supplemental Figure 8). During an infant's first 100 breaths (or total if <100), $48 \%$ of FRC change occurred by the fifth breath.

\section{Regional ventilation patterns}

Ventilation redistributed towards the dorsal regions with time for both crying and tidal breaths (Figure 1); $\mathrm{CoV}_{\mathrm{VD}} \mathrm{p}=0.045$ and $\mathrm{p}<0.0001$ respectively. Overall, $\mathrm{CoV}_{\mathrm{VD}}$ favoured the ventral regions during crying compared to tidal breaths by a mean $(95 \% \mathrm{CI}) 1.6(0.3,2.9) \%$, although the differences were not significant within each minute. The redistribution of $\mathrm{V}_{\mathrm{T}}$ towards the dorsal regions was predominantly due to increased $\mathrm{V}_{\mathrm{T}}$ within central lregions during crying, and the dorsal region during tidal breaths $(\mathrm{p}=0.0004)$, both at the expense of ventral $\mathrm{V}_{\mathrm{T}}$.

Both breath types resulted in greater ventilation in the right lung (Figure 4). During crying a mean (SD) 82.2 (15.3)\% of total $\mathrm{V}_{\mathrm{T}}$ occurring in the right lung during the first $60 \mathrm{~s}\left(\mathrm{CoV}_{\mathrm{RL}} 3.0\right.$ (9.1)\%; ideal 46\%), increasing within the left lung with time $(\mathrm{p}=0.011)$. By $240 \mathrm{~s} 64.3(11.4) \%$ of $\mathrm{V}_{\mathrm{T}}$ 
occurred within the right lung $\left(\mathrm{CoV}_{\mathrm{RL}} 43.1(6.5) \%\right)$. The right lung accounted for predominance of $59.5(14.3) \%$ of $\mathrm{V}_{\mathrm{T}}\left(\mathrm{CoV}_{\mathrm{RL}} 46.4(9.3) \%\right)$ during tidal breaths within the first $60 \mathrm{~s}$, and this predominance did not change over time $(\mathrm{p}=0.10)$. Crying resulted in greater right-left lung inhomogeneity, with $\mathrm{CoV}_{\mathrm{RL}}$ being a mean $(95 \% \mathrm{CI}) 2.0(0.5,3.5) \%$ less overall than tidal breaths, and the difference greatest in the first minute; $13.4(6.7,20.1) \%$.

Approximately $10 \%$ of predefined lung regions were unventilated for both tidal and crying breaths, with not difference in the ventrodorsal pattern of unventilated regions (Supplementary Figure 9). After 240s there was less unventilated lung regions, especially during tidal breathing, suggesting increasing aeration resulted in greater engagement of the distal lung in ventilation.

\section{DISCUSSION}

The transition to air-breathing at birth is a seminal physiological event essential to life in all humans. In our observational study we provide the first detailed description of the volumetric processes within the lung at birth. We found that the transition to air-breathing is characterised by complex spatiotemporal patterns of aeration and ventilation initially mediated by high PIF rates and prolonged expiration. Overall this results in rapid lung aeration that moves from the central to distal lung, with the right lung engaging in ventilation earlier than the left. Crying, the dominant breathing pattern at birth, creates greater PIF and complex expiratory volume patterns, including pendulluft flows, more suited to both rapid aeration and maintenance of FRC than tidal breathing, at a time the lung is still likely to be partially fluid-filled. That these findings occurred in healthy term infants without instrumentation or active intervention is important, providing the first human evidence that successful aeration at birth is dependent on actively engaging in expiratory mechanisms to protect

\section{FRC (Figure 5).}


Clearing the respiratory system of fetal lung liquid, and establishing aeration is essential to physiological success at birth. We showed that the majority of lung aeration is rapidly achieved at birth, similar to chest radiography studies during the first seconds after birth in term infants. $(7,8)$ Unlike these studies we were able to continuously follow the process of aeration beyond the first inflations. Although there was considerable inter-subject variability, aeration conformed with an exponential pattern reported in preclinical studies, $(3,4,23,30,31)$ and during lung recruitment in the already-aerated lung.(32,33) Aeration was also associated with a temporal increase in distal lung ventilation. Our study is the first in humans to confirm the sequential central-distal movement of the air-fluid interface during aeration from the major airways to the distal alveoli reported in animal studies is ongoing beyond the first few breaths.(1,9) EIT can not directly measure airspace fluid, but the markedly different electrical properties of air and fluid make EIT ideally suited to mapping the air-fluid interface and tracking lung aeration clinically.

The patterns of ventilation indicate that spatiotemporal aeration after birth is more complex than only a central-distal process. The preferential ventilation of the right lung was unexpected but biologically plausible. At birth the lung is fluid filled, and airways (and tissue) have a high resistance.(34) The left main bronchus exits the carina acutely, and is encumbered by the heart. This may create preferential flow states towards the right lung, especially during the higher inspiratory flows of crying. Resistance falls in those areas of the lung that aerate first, further potentiating ventilation compared to unaerated regions. Our data also suggests that ventilation initially follows a gravity-dependent pattern, similar to that seen in parenchymal lung diseases. $(35,36)$ Once aerated the lung rapidly develops the anatomical ventrodorsal pattern of ventilation reported in healthy older infants, favouring the dorsal lung with its increased lung mass and greater diaphragmatic tidal movement.(19,37) These changing spatiotemporal patterns across multiple planes make applying respiratory support without risking lung injury particularly challenging. 
As expected in healthy infants, during the first two minutes $80 \%$ of breaths were cries. In a similar population of 13 infants, $77 \%$ of the analysed 749 breaths within the first 90 seconds after birth were classified as cries or grunts, but breath classification was performed post hoc from face mask measurements without auditory or visual confirmation, limiting interpretability.(16) Our study is the first to classify volume changes with flow and breathing behaviour. Crying created different flow characteristics than tidal breathing, quickly inflating the lung with faster Ti and PIF. This is advantageous within the highly resistive fluid-filled lung at birth,(34) but once aerated provides little mechanical or gas exchange benefit. We postulate that crying has a de novo physiological purpose, and not simply due to the noxious stress response of birth. Once aerated the high PIF conditions of crying increase unventilated lung tissue, with infants switching to the more advantageous tidal breaths.

Importantly, crying is also an expiratory phenomenon, being associated with slow expiratory flows, longer Te and $\tau$. Volume loss during expiration followed a unique bifid pattern, occurring in $71 \%$ of all cries and rarely in tidal inflations. This pattern of volume change represents transient periods of minimal airway flow despite the chest wall being in a state of expiratory recoil. In this state reducing expiratory flow could only be achieved via active means, such as glottic closure or diaphragmatic hold; both seen in radiological imaging at birth.(8) The lung is in a state of flux in early ex-utero life; the alveoli maybe air-filled but fetal lung fluid remains in the interstitium, and fluid can influx back into alveoli if the intrathoracic pressure gradient falls, compromising FRC. $(4,9,34)$ It has been proposed that 'expiratory braking' is essential during this period, $(1,5,7,8,17,18,38)$ and flow patterns measured at the airway opening support this, but have not been correlated to temporal FRC change.(16) Our study provides the first evidence that expiratory braking does more than just prevent egress of gas from the lungs. It also facilitates the volumetric conditions needed to preserve FRC, and importantly redistributes gas within the lungs (pendelluft flow). We propose that this provides a simple visual indicator of an infant's independent 
ability to independently support respiratory transition. Further studies are warranted to determine if the same breath types, and patterns, are present in at risk and preterm infants.

Reports of the cardiorespiratory processes at birth are sparse, mainly due to challenges in measurement. Following chest radiology studies in the 1960 s, $(7,8)$ instrumentation within the mouth, initially with bulky equipment, $(5,17,18,38)$ and more recently, face masks $(16,39,40)$ have measured airway opening flow, $\mathrm{V}_{\mathrm{T}}$, expired $\mathrm{CO}_{2}$ and/or pressure changes, and infer intrathoracic conditions. Face masks are frequently applied with a leak,(41,42) application interferes with normal breathing efforts,(43) and cannot identify important spatiotemporal events, limiting usefulness during spontaneous breathing. Ideally measurements should be obtained from the thorax without impacting respiratory effort. Recently respiratory inductive plethysmography(39) and lung ultrasound(15) have been used in the delivery room. Inductive plethysmography requires two belts and determines lung volume from measuring the cross-sectional areas of the chest and abdomen, which may not change between fluid- and air-filled states.(32) Lung ultrasound is ideal for imaging the air-fluid interface, is simple to use, but lacks regional resolution, and continuous imaging has not been possible.(15) In this context, EIT is attractive. EIT is an established and validated method of measuring relative change in multiple spatiotemporal respiratory parameters.(19) EIT is radiation-free and available with a simple non-invasive belt (25) that could be applied as quickly, and more reliably, than pulse oximetry. EIT also confirmed the physiological patterns seen in humans and preclinical studies using these other measurement tools. $(2,9,23) \mathrm{We}$ contend that EIT is currently the best method of monitoring the respiratory system at birth.

\section{Limitations}

Our study was limited to birth via elective caesarean section, and measuring were not made from delivery of the chest. The birth experience is uniquely personal, and we intentionally limited our study to a period of clinical mother-baby separation. Consequently, we missed the first few 
medRxiv preprint doi: https://doi.org/10.1101/2020.07.29.20161166; this version posted October 26, 2020. The copyright holder for this preprint

inflations in most infants. We content that these inflations are unlikely to be markedly different from those we captured. The unique volumetric, flow and FRC characteristics we identified indicate fluid clearance was still ongoing during the first 120s. It is unlikely that the enhanced lung liquid clearance provided by delivery through the vaginal canal would alter the respiratory findings in our healthy term population with active vigorous breathing. Respiratory effort was not suppressed, but data on all modes of delivery are needed in less vigorous infants. We have demonstrated that EIT can be practically applied earlier and during vaginal delivery. Our study of 1401 inflations from 17 infants is one of the largest, but, like previous studies, $(16,17)$ exclusions were necessary and may have included potentially important breaths. In part this was intentional; our methodology was designed to minimise artefact and ensure correct breath classification lacking in previous studies. It is possible that respiratory drive occurred with an occluded airway. This would not result in a volume change on EIT but is an important physiological finding that should be seen on video. Like all other imaging tools used to describe the respiratory transition, EIT is limited to a single slice of the lung. However, single slice EIT has been shown to represent whole lung patterns in infants.(19) EIT cannot measure intrathoracic pressure. To do so would require invasive instrumentation, but is unnecessary as flow patterns reflect intrathoracic pressure states.

\section{Conclusions}

This study provides the first detailed description of the respiratory behaviour of the healthy human lung during the transition to air-breathing after birth. Birth requires rapid aeration of the lung, and is achieved predominately via crying. Crying creates unique flow and volume states not seen elsewhere in respiratory physiology, and is characterised by high peak inspiratory flow and expiratory braking to preserve attained FRC and allow volume redistribution. The right lung ventilates before the left lung after birth, and the lung quickly develops an anatomical pattern of ventrodorsal ventilation once aerated. Understanding how the human lung successfully commences breathing at birth is the first step in developing tools to identifying when intervention is required. 
medRxiv preprint doi: https://doi.org/10.1101/2020.07.29.20161166; this version posted October 26, 2020. The copyright holder for this preprint

(which was not certified by peer review) is the author/funder, who has granted medRxiv a license to display the preprint in perpetuity.

All rights reserved. No reuse allowed without permission.

Acknowledgements: The authors wish to thank the families, infants and Royal Women's Hospital staff involved in the study. The authors acknowledge Dr Kate Patterson of Medipics and Prose for assistance with figures and videos. The authors also acknowledge the assistance of Dr Louise Owen and Dr C. Omar Kamlin at the Royal Women's Hospital for advice on study implementation in the delivery room. 
medRxiv preprint doi: https://doi.org/10.1101/2020.07.29.20161166; this version posted October 26, 2020. The copyright holder for this preprint

(which was not certified by peer review) is the author/funder, who has granted medRxiv a license to display the preprint in perpetuity.

All rights reserved. No reuse allowed without permission.

\section{References}

1. Hooper SB, Te Pas AB, Kitchen MJ. Respiratory transition in the newborn: a three-phase process. Arch Dis Child Fetal Neonatal Ed 2016; 101: F266-271.

2. Tingay DG, Pereira-Fantini PM, Oakley R, McCall KE, Perkins EJ, Miedema M, Sourial M, Thomson J, Waldmann A, Dellaca RL, Davis PG, Dargaville PA. Gradual Aeration at Birth is More Lung Protective than a Sustained Inflation in Preterm Lambs. Am J Respir Crit Care Med 2019; 200: 609-616.

3. Tingay DG, Rajapaksa A, Zonneveld CE, Black D, Perkins EJ, Adler A, Grychtol B, Lavizzari A, Frerichs I, Zahra VA, Davis PG. Spatiotemporal Aeration and Lung Injury Patterns Are Influenced by the First Inflation Strategy at Birth. Am J Respir Cell Mol Biol 2016; 54: 263 272.

4. Tingay DG, Lavizzari A, Zonneveld CE, Rajapaksa A, Zannin E, Perkins E, Black D, Sourial M, Dellaca RL, Mosca F, Adler A, Grychtol B, Frerichs I, Davis PG. An individualized approach to sustained inflation duration at birth improves outcomes in newborn preterm lambs. Am J Physiol Lung Cell Mol Physiol 2015; 309: L1138-1149.

5. Milner AD, Vyas H. Lung expansion at birth. J Pediatr 1982; 101: 879-886.

6. van Vonderen JJ, Te Pas AB. The first breaths of life: imaging studies of the human infant during neonatal transition. Paediatr Respir Rev 2015; 16: 143-146.

7. Fawcitt J, Lind J, Wegelius C. The first breath: a preliminary communication describing some methods of investigation of the first breath of a baby and the results obtained from them. Acta Paediatr Suppl 1960; 49(Suppl 123): 5-17.

8. Bosma JF, Lind J. Roentgenologic observations of motions of the upper airway associated with establishment of respiration in the newborn infant. Acta Paediatr Suppl 1960; 49 (Suppl 123): $18-55$. 
medRxiv preprint doi: https://doi.org/10.1101/2020.07.29.20161166; this version posted October 26, 2020. The copyright holder for this preprint

(which was not certified by peer review) is the author/funder, who has granted medRxiv a license to display the preprint in perpetuity.

All rights reserved. No reuse allowed without permission.

9. Hooper SB, Kitchen MJ, Wallace MJ, Yagi N, Uesugi K, Morgan MJ, Hall C, Siu KK, Williams

IM, Siew M, Irvine SC, Pavlov K, Lewis RA. Imaging lung aeration and lung liquid clearance at birth. FASEB J 2007; 21: 3329-3337.

10. O'Donnell CP, Gibson AT, Davis PG. Pinching, electrocution, ravens' beaks, and positive pressure ventilation: a brief history of neonatal resuscitation. Arch Dis Child Fetal Neonatal Ed 2006; 91: F369-373.

11. Perlman JM, Wyllie J, Kattwinkel J, Wyckoff MH, Aziz K, Guinsburg R, Kim HS, Liley HG, Mildenhall L, Simon WM, Szyld E, Tamura M, Velaphi S, Neonatal Resuscitation Chapter C. Part 7: Neonatal Resuscitation: 2015 International Consensus on Cardiopulmonary Resuscitation and Emergency Cardiovascular Care Science With Treatment Recommendations. Circulation 2015; 132: S204-241.

12. Tingay DG, Togo A, Pereira-Fantini PM, Miedema M, McCall KE, Perkins EJ, Thomson J, Dowse G, Dellaca RL, Davis PG, Dargaville PA. Aeration strategy at birth influences the physiological response to surfactant in preterm lambs. Arch Dis Child Fetal Neonatal Ed 2019.

13. Manley BJ, Owen LS, Hooper SB, Jacobs SE, Cheong JLY, Doyle LW, Davis PG. Towards evidence-based resuscitation of the newborn infant. Lancet 2017; 389: 1639-1648.

14. Karlberg P. The adaptive changes in the immediate postnatal period, with particular reference to respiration. J Pediatr 1960; 56: 585-604.

15. Blank DA, Kamlin COF, Rogerson SR, Fox LM, Lorenz L, Kane SC, Polglase GR, Hooper SB, Davis PG. Lung ultrasound immediately after birth to describe normal neonatal transition: an observational study. Arch Dis Child Fetal Neonatal Ed 2018; 103: F157-F162.

16. te Pas AB, Wong C, Kamlin CO, Dawson JA, Morley CJ, Davis PG. Breathing patterns in preterm and term infants immediately after birth. Pediatr Res 2009; 65: 352-356.

17. Vyas H, Milner AD, Hopkins IE. Intrathoracic pressure and volume changes during the spontaneous onset of respiration in babies born by cesarean section and by vaginal delivery. $J$ Pediatr 1981; 99: 787-791. 
medRxiv preprint doi: https://doi.org/10.1101/2020.07.29.20161166; this version posted October 26, 2020. The copyright holder for this preprint (which was not certified by peer review) is the author/funder, who has granted medRxiv a license to display the preprint in perpetuity.

All rights reserved. No reuse allowed without permission.

18. Boon AW, Milner AD, Hopkin IE. Physiological responses of the newborn infant to resuscitation. Arch Dis Child 1979; 54: 492-498.

19. Frerichs I, Amato MB, van Kaam AH, Tingay DG, Zhao Z, Grychtol B, Bodenstein M, Gagnon H, Bohm SH, Teschner E, Stenqvist O, Mauri T, Torsani V, Camporota L, Schibler A, Wolf GK, Gommers D, Leonhardt S, Adler A, group Ts. Chest electrical impedance tomography examination, data analysis, terminology, clinical use and recommendations: consensus statement of the TRanslational EIT developmeNt stuDy group. Thorax 2017; 72: 83-93.

20. Tingay DG, Rajapaksa A, Zannin E, Pereira-Fantini PM, Dellaca RL, Perkins EJ, Zonneveld CE, Adler A, Black D, Frerichs I, Lavizzari A, Sourial M, Grychtol B, Mosca F, Davis PG. Effectiveness of individualized lung recruitment strategies at birth: an experimental study in preterm lambs. Am J Physiol Lung Cell Mol Physiol 2017; 312: L32-L41.

21. Milesi I, Tingay DG, Lavizzari A, Bianco F, Zannin E, Tagliabue P, Mosca F, Ventura ML, Rajapaksa A, Perkins EJ, Black D, Di Castri M, Sourial MD, Pohlmann G, Dellaca RL. Supraglottic Atomization of Surfactant in Spontaneously Breathing Lambs Receiving Continuous Positive Airway Pressure. Pediatr Crit Care Med 2017.

22. McCall KE, Waldmann AD, Pereira-Fantini P, Oakley R, Miedema M, Perkins EJ, Davis PG, Dargaville PA, Bohm SH, Dellaca R, Sourial M, Zannin E, Rajapaksa AE, Tan A, Adler A, Frerichs I, Tingay DG. Time to lung aeration during a sustained inflation at birth is influenced by gestation in lambs. Pediatr Res 2017; 82: 712-720.

23. Tingay DG, Bhatia R, Schmolzer GM, Wallace MJ, Zahra VA, Davis PG. Effect of sustained inflation vs. stepwise PEEP strategy at birth on gas exchange and lung mechanics in preterm lambs. Pediatr Res 2014; 75: 288-294.

24. Tingay DG, Waldmann AD, Frerichs I, Ranganathan S, Adler A. Electrical Impedance Tomography Can Identify Ventilation and Perfusion Defects: A Neonatal Case. Am J Respir Crit Care Med 2019; 199: 384-386. 
medRxiv preprint doi: https://doi.org/10.1101/2020.07.29.20161166; this version posted October 26, 2020. The copyright holder for this preprint

(which was not certified by peer review) is the author/funder, who has granted medRxiv a license to display the preprint in perpetuity.

All rights reserved. No reuse allowed without permission.

25. Sophocleous L, Frerichs I, Miedema M, Kallio M, Papadouri T, Karaoli C, Becher T, Tingay

DG, van Kaam AH, Bayford R, Waldmann AD. Clinical performance of a novel textile interface for neonatal chest electrical impedance tomography. Physiol Meas 2018; 39: 044004.

26. Miedema M, Waldmann A, McCall KE, Bohm SH, van Kaam AH, Tingay DG. Individualized Multiplanar Electrical Impedance Tomography in Infants to Optimize Lung Monitoring. Am J Respir Crit Care Med 2017; 195: 536-538.

27. Adler A, Lionheart WR. Uses and abuses of EIDORS: an extensible software base for EIT. Physiol Meas 2006; 27: S25-42.

28. Adler A, Arnold JH, Bayford R, Borsic A, Brown B, Dixon P, Faes TJ, Frerichs I, Gagnon H, Garber Y, Grychtol B, Hahn G, Lionheart WR, Malik A, Patterson RP, Stocks J, Tizzard A, Weiler N, Wolf GK. GREIT: a unified approach to 2D linear EIT reconstruction of lung images. Physiol Meas 2009; 30: S35-55.

29. Frerichs I, Becher T. Chest electrical impedance tomography measures in neonatology and paediatrics-a survey on clinical usefulness. Physiol Meas 2019; 40: 054001.

30. Siew ML, Te Pas AB, Wallace MJ, Kitchen MJ, Lewis RA, Fouras A, Morley CJ, Davis PG, Yagi N, Uesugi K, Hooper SB. Positive end-expiratory pressure enhances development of a functional residual capacity in preterm rabbits ventilated from birth. $J$ Appl Physiol 2009; 106: $1487-1493$.

31. te Pas AB, Siew M, Wallace MJ, Kitchen MJ, Fouras A, Lewis RA, Yagi N, Uesugi K, Donath S, Davis PG, Morley CJ, Hooper SB. Establishing functional residual capacity at birth: the effect of sustained inflation and positive end-expiratory pressure in a preterm rabbit model. Pediatr Res 2009; 65: 537-541.

32. Tingay DG, Mills JF, Morley CJ, Pellicano A, Dargaville PA. The deflation limb of the pressure-volume relationship in infants during high-frequency ventilation. Am J Respir Crit Care Med 2006; 173: 414-420. 
medRxiv preprint doi: https://doi.org/10.1101/2020.07.29.20161166; this version posted October 26, 2020. The copyright holder for this preprint

(which was not certified by peer review) is the author/funder, who has granted medRxiv a license to display the preprint in perpetuity.

All rights reserved. No reuse allowed without permission.

33. Miedema M, de Jongh FH, Frerichs I, van Veenendaal MB, van Kaam AH. Regional respiratory time constants during lung recruitment in high-frequency oscillatory ventilated preterm infants. Intensive Care Med 2012; 38: 294-299.

34. Veneroni C, Tingay DG, McCall KE, Pereira-Fantini PM, Perkins EJ, Dargaville PA, Dellaca RL. Respiratory mechanics during initial lung aeration at birth in the preterm lamb. Am J Physiol Lung Cell Mol Physiol 2020.

35. Miedema M, de Jongh FH, Frerichs I, van Veenendaal MB, van Kaam AH. Changes in lung volume and ventilation during lung recruitment in high-frequency ventilated preterm infants with respiratory distress syndrome. J Pediatr 2011; 159: 199-205 e192.

36. Gattinoni L, Caironi P, Pelosi P, Goodman LR. What has computed tomography taught us about the acute respiratory distress syndrome? Am J Respir Crit Care Med 2001; 164: 1701-1711.

37. Pham TM, Yuill M, Dakin C, Schibler A. Regional ventilation distribution in the first 6 months of life. Eur Respir J 2011; 37: 919-924.

38. Boon AW, Milner AD, Hopkin IE. Lung expansion, tidal exchange, and formation of the functional residual capacity during resuscitation of asphyxiated neonates. J Pediatr 1979; 95 : 1031-1036.

39. van Vonderen JJ, Lista G, Cavigioli F, Hooper SB, te Pas AB. Effectivity of ventilation by measuring expired $\mathrm{CO} 2$ and RIP during stabilisation of preterm infants at birth. Arch Dis Child Fetal Neonatal Ed 2015; 100: F514-518.

40. Hooper SB, Fouras A, Siew ML, Wallace MJ, Kitchen MJ, Te Pas AB, Klingenberg C, Lewis RA, Davis PG, Morley CJ, Schmolzer GM. Expired CO2 Levels Indicate Degree of Lung Aeration at Birth. PloS one 2013; 8: e70895.

41. Schmolzer GM, Dawson JA, Kamlin CO, O'Donnell CP, Morley CJ, Davis PG. Airway obstruction and gas leak during mask ventilation of preterm infants in the delivery room. Arch Dis Child Fetal Neonatal Ed 2011; 96: F254-257. 
medRxiv preprint doi: https://doi.org/10.1101/2020.07.29.20161166; this version posted October 26, 2020. The copyright holder for this preprint

(which was not certified by peer review) is the author/funder, who has granted medRxiv a license to display the preprint in perpetuity.

All rights reserved. No reuse allowed without permission.

42. Schmolzer GM, Kamlin OC, O'Donnell CP, Dawson JA, Morley CJ, Davis PG. Assessment of tidal volume and gas leak during mask ventilation of preterm infants in the delivery room. Arch Dis Child Fetal Neonatal Ed 2010; 95: F393-397.

43. Kuypers K, Lamberska T, Martherus T, Dekker J, Bohringer S, Hooper SB, Plavka R, Te Pas $\mathrm{AB}$. The effect of a face mask for respiratory support on breathing in preterm infants at birth. Resuscitation 2019; 144: 178-184. 


\section{FIGURE LEGENDS}

Figure 1. A. Relative Volume change $\left(\Delta \mathrm{V}_{\mathrm{L}}\right)$ over time within the whole lung during the two representative breaths for crying $\left(\mathbf{i} ; 25 \mathrm{~s}\right.$ ) and tidal breaths (ii; $5 \mathrm{~min}$ ). B. $\Delta \mathrm{V}_{\mathrm{L}}$ during the same breaths within the ventral (blue) and dorsal (red) hemithoraces. C. Ventrodorsal centre of ventilation $\left(\mathrm{CoV}_{\mathrm{VD}}\right)$ by minute after birth for crying and tidal breaths. $\mathrm{CoV}_{\mathrm{VD}}$ of $55 \%$ represents uniform ventilation, with values $<55 \%$ indicating relatively greater ventilation in the ventral lung and $>55 \%$ the dorsal lung. Grey dots represent individual breath data, and black line and bars

mean \pm SD. C. Relative distribution of ventilation $\left(\%\right.$ total $\left.V_{T}\right)$ along the gravity dependent plane for crying and tidal breaths in the most gravity dependent third of the lung (black bars), central third (grey bars) and non-gravity dependent third (white bars), with solid bars being right lung region and dotted bars left lung. All data mean+SD. ${ }^{*} \mathrm{p}<0.05, * * \mathrm{p}<0.01, * * * \mathrm{p}<0.0001$ against first 60 s (mixedeffects model).

Figure 2. Ti (A), Te $(\mathbf{B})$, respiratory system time constant $(\tau ; \mathbf{C}), \operatorname{PIF}(\mathbf{D})$ and PEF $(\mathbf{E})$. Black circles indicate crying breaths and white diamonds tidal breaths. All data mean \pm SD. $* p<0.05$, $* * \mathrm{p}<0.01, * * * \mathrm{p}<0.0001$ cry vs tidal inflation; $\dagger \mathrm{p}<0.01$ within breath type (all mixed-effects model).

Figure 3. A. Change $(\Delta)$ in FRC from first measured inflation for all breaths $(\mathbf{A})$ and for the first 100 inflations (maximum)(B). $\triangle \mathrm{FRC}$ normalised to the FRC before the first breath $(0 \%)$ and maximum FRC (100\%) for each infant. A. Blue line represents line of best fit (dashed lines $95 \%$ CI) using a one-phase exponential association; $\mathrm{y}=\mathrm{y}_{\text {plateau. }}\left[1-e^{\mathrm{x} . \tau-1}\right]$; plateau (95\% CI) $56.2(54.0$, $58.6) \%, \tau 8.0(6.0,10.5)$ inflations $\left(\mathrm{R}^{2} 0.14\right.$, RSME $24.5 \%$, replicates test discrepancy (F) 0.82 $[\mathrm{p}=0.96])$. Grey dashed lines demonstrate $\triangle \mathrm{FRC}$ at $50 \%$ of $\mathrm{FRC}_{\max }$ and 50 inflations. B. Black circles represent the mean $\triangle \mathrm{FRC}$ every 5 inflations for each infant, and dashed lines $95 \% \mathrm{CI}$. 
Figure 4. A. Relative Volume change $\left(\Delta \mathrm{V}_{\mathrm{L}}\right)$ over time within the right (blue) and left (red) lung during the two representative breaths for crying (i; $25 \mathrm{~s}$ ) and tidal breaths (ii; $5 \mathrm{~min}$ ). B. Functional EIT images of volume change within the lungs for the same breaths using the colour scale defined in Supplementary Video 2. C. Relative distribution of ventilation $\left(\%\right.$ total $\mathrm{V}_{\mathrm{T}}$ ) in the right (black bars) and left (white bars) lung for crying and tidal breaths. D. Centre of ventilation $\left(\mathrm{CoV}_{\mathrm{RL}}\right)$ along the right-left plane for all inflations by minute after birth for crying and tidal breaths. $\mathrm{CoV}_{\mathrm{RL}}$ of $46 \%$ represents uniform ventilation, with values $<46 \%$ indicating relatively greater ventilation in the right lung, and $>46 \%$ greater ventilation in the left lung. All data mean $\pm \mathrm{SD}$, and dots individual breath data. Panel A and C; *p<0.05, ***p<0.0001 (mixed-effects model). Panel B and D; *p<0.05, $* * \mathrm{p}<0.01$ against first $60 \mathrm{~s} . \dagger \mathrm{p}<0.05$ against 181-240s.

\section{Figure 5. Summary of main findings and hypothesed explaination of the criteria which define}

the respiratory events within the lungs at birth. Representative global lung volume change during a single cry at $14 \mathrm{~s}$ after birth (Infant 6; Panel A) demonstrating the dynamic volume change during inspiration and expiration, and resultant increase in end-expiratory FRC. The breath has been divided into five phases related to the mechanistic events identified during the respiratory transition from a fluid-filled to aerated lung (Panel B), and the respective fEIT images for each shown in Panel C. At the start of the inflation the airways and alveoli are fluid filled (Column 1). A cry initiates a rapid and large contraction of the diaphragm with a resultant rapid inspiratory flow (slope of the time-volume curve) and high inflating (driving) pressure within the lung generating aeration by moving fluid from the proximal airways to the alveoli (enlarged) and then the lung interstitium (Column 2). Expiration begins with rapid contraction of the diaphragm (Column 3). The fall in intra-thoracic pressure during expiration lowers intra-alveolar pressure, and in some lung units this fall allows fetal fluid to influx back into the alveoli spaces. To counteract this effect the neonate slows (brakes) diaphragmatic contraction and partially closes the glottis, thus transiently repressurising the lung and allowing pendulluft gas flow between aerated to poorly aerated lung units 
medRxiv preprint doi: https://doi.org/10.1101/2020.07.29.20161166; this version posted October 26, 2020. The copyright holder for this preprint

(which was not certified by peer review) is the author/funder, who has granted medRxiv a license to display the preprint in perpetuity.

All rights reserved. No reuse allowed without permission.

(Column 4). When expiration continues it does so against a partially closed glottis which mediates slower expiratory gas flow and allows some gas to remain in the lungs, thus generating a greater end-expiration FRC (Column 5) and more favourable lung conditions at the start of the next inflation. 
Table 1. Type of breath by time

\begin{tabular}{|c|c|c|c|c|c|c|}
\hline \multirow{2}{*}{$\mathrm{n}=1401$ included inflations } & \multicolumn{6}{|c|}{ Time from birth (s) } \\
\hline & $0-60$ & $61-120$ & 121-180 & $181-240$ & 241-360 & Total \\
\hline Cry & 55 & 186 & 221 & 188 & 137 & 787 \\
\hline Tidal & 13 & 48 & 106 & 189 & 258 & 614 \\
\hline $\operatorname{Cry}(\%) *$ & $80.9 \%$ & $79.5 \%$ & $67.6 \%$ & $49.9 \%$ & $34.7 \%$ & $56.2 \%$ \\
\hline Median (minimum, maximum) cry/infant & $6(2,21)$ & $13(3,22)$ & $13(3,52)$ & $12(1,63)$ & $15(1,48)$ & $11(1,63)$ \\
\hline Median (minimum, maximum) tidal/infant & $7(4,9)$ & $4(1,13)$ & $9(1,20)$ & $11(2,44)$ & $15(4,102)$ & $9(1,102)$ \\
\hline
\end{tabular}

* $\mathrm{p}<0.0001$; chi-squared test for trend. 

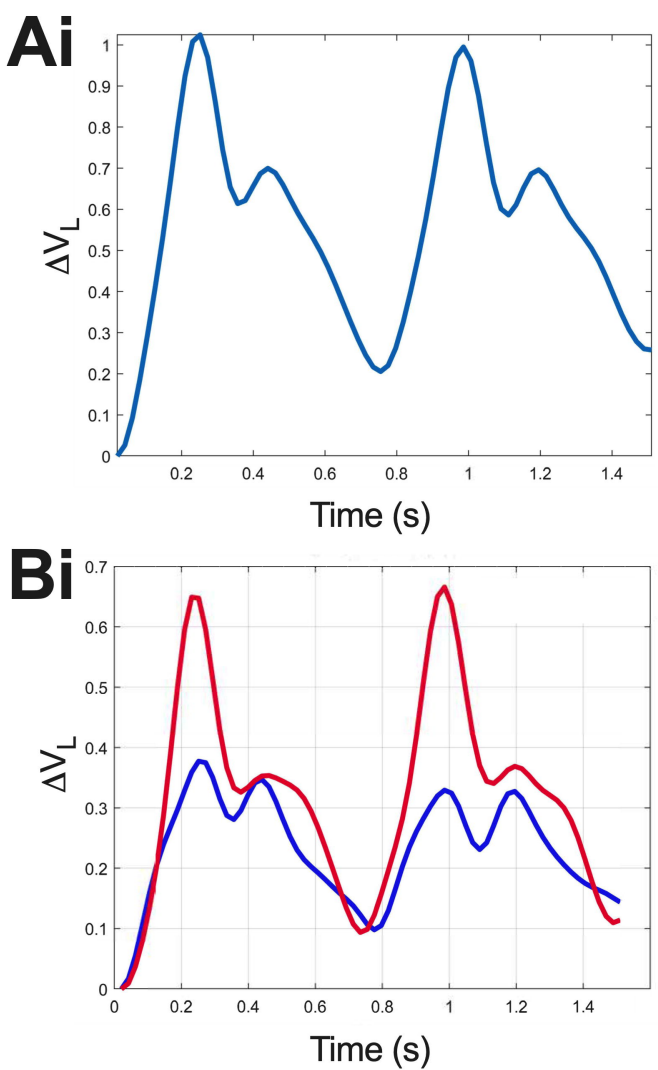

$\mathrm{Ci}$

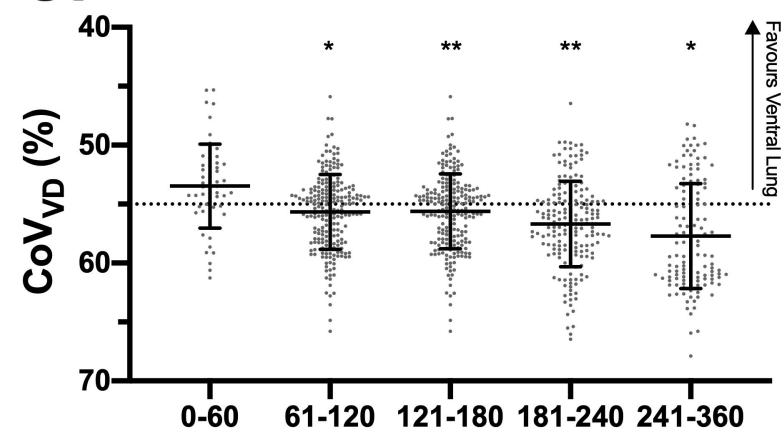

Di

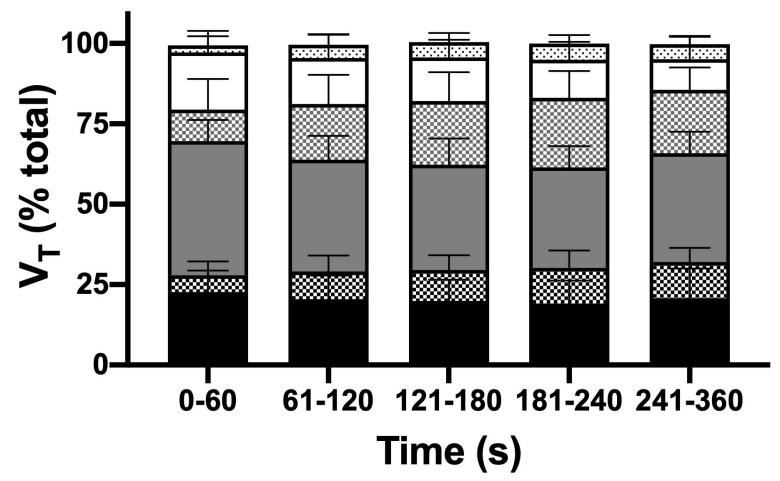

Aii

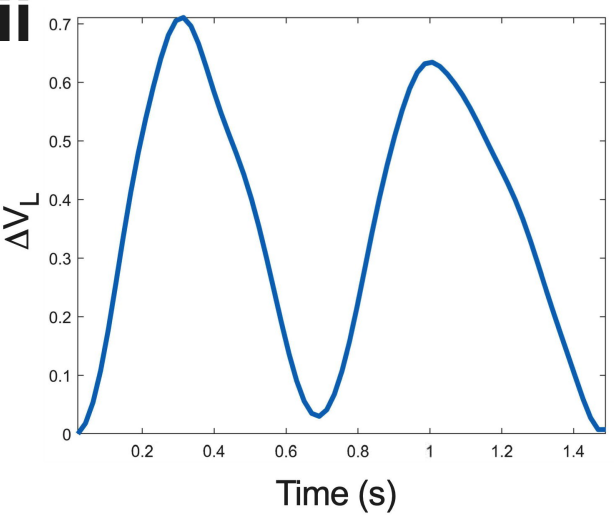

Bii

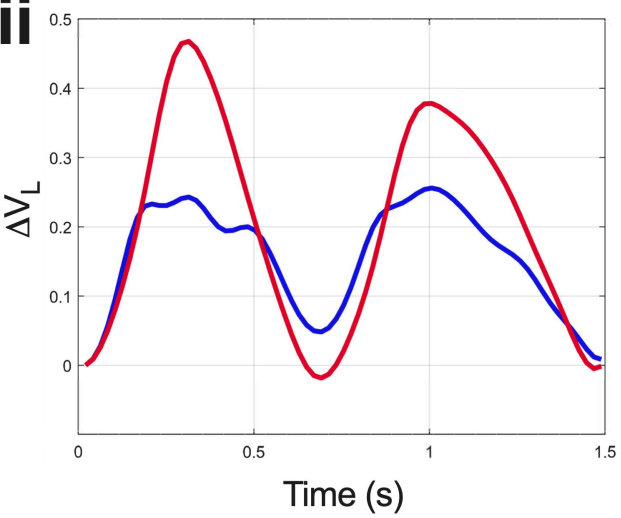

Cii

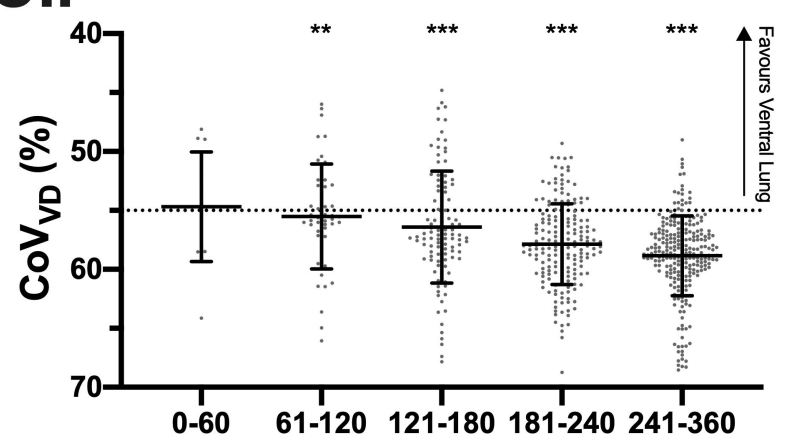

Dii

Time (s)

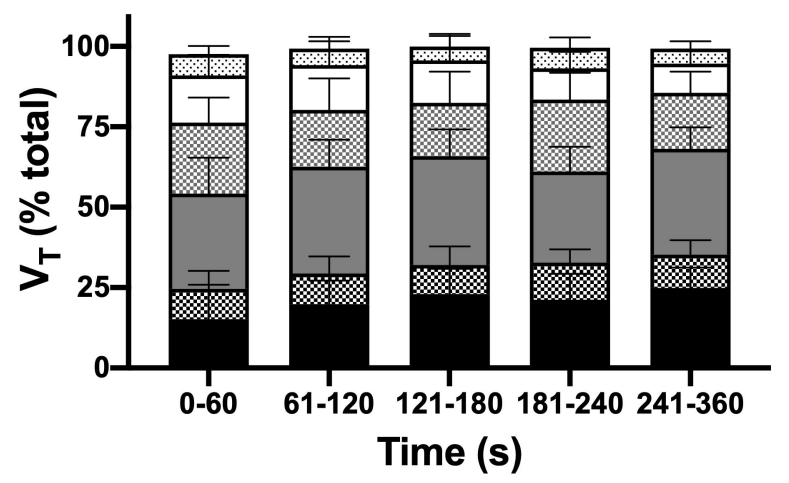




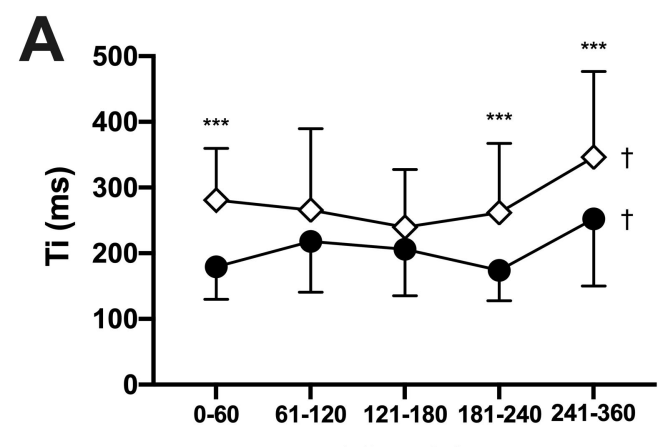

Time (s)
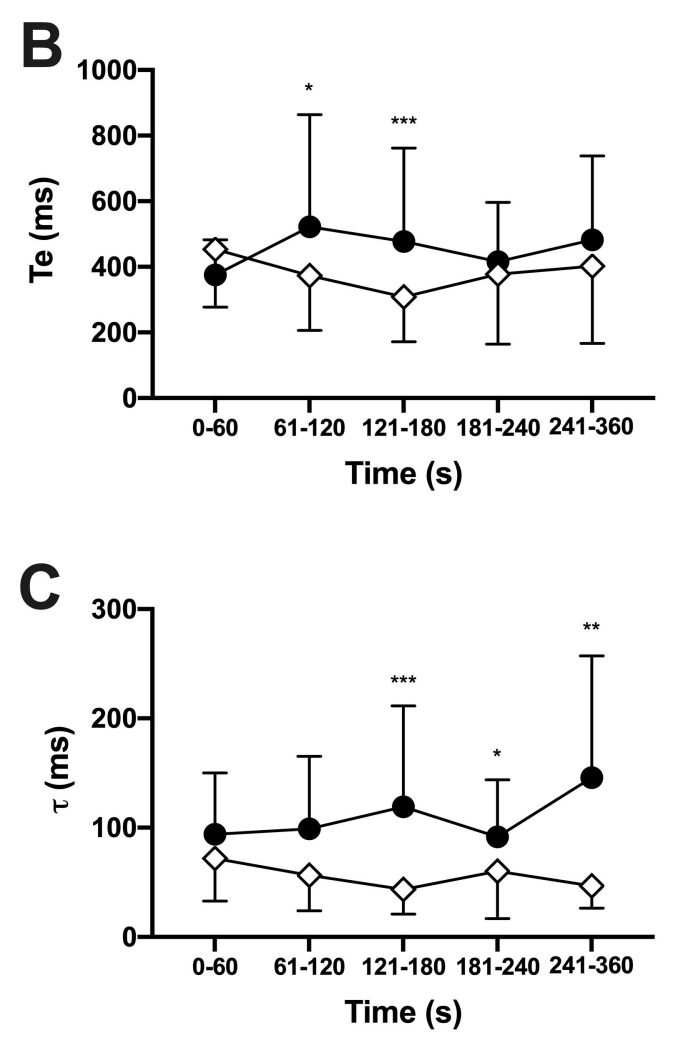

D

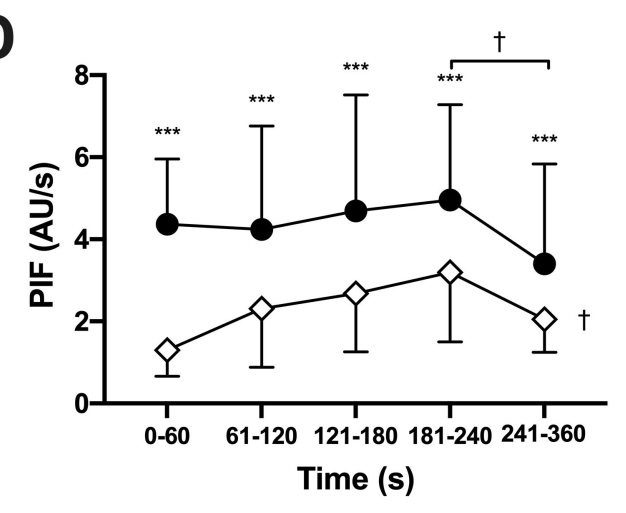

E

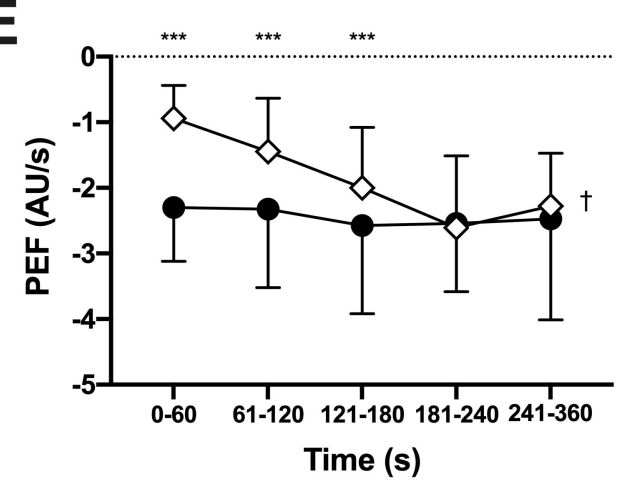


A $\quad$ B
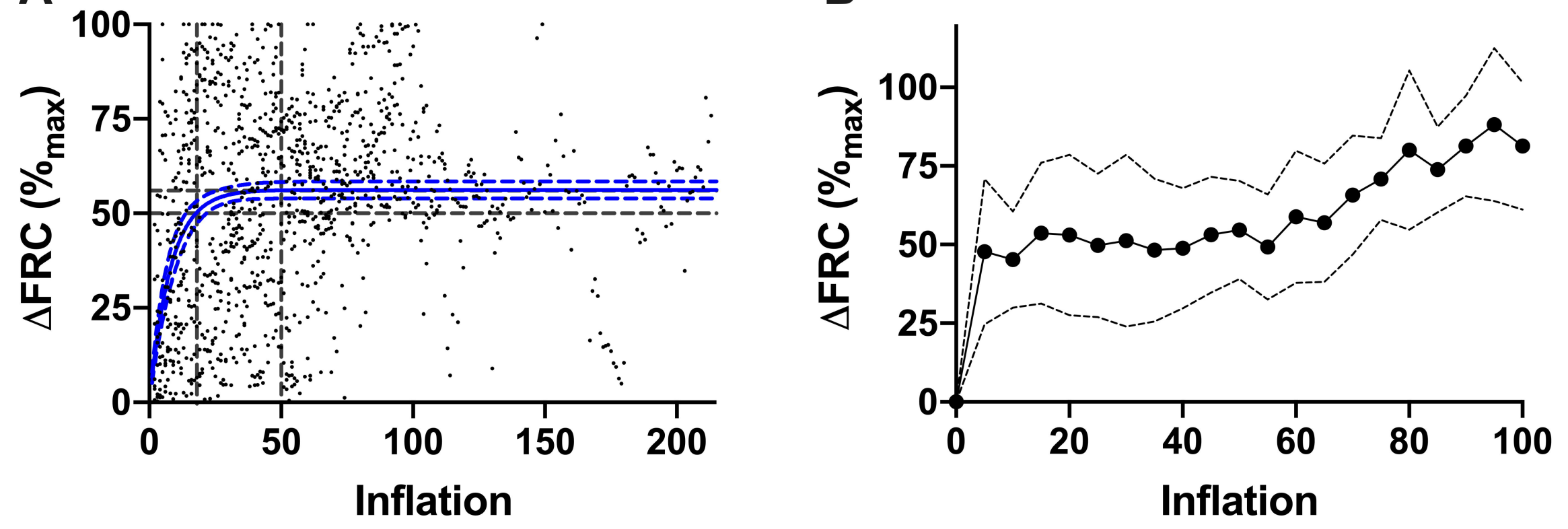

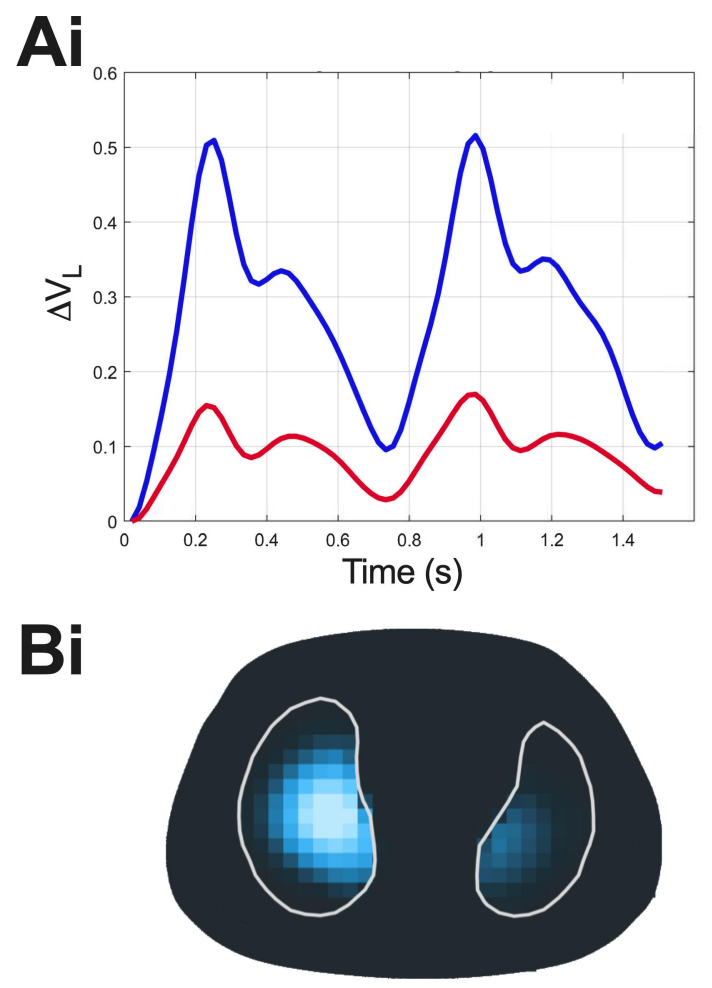

Aii
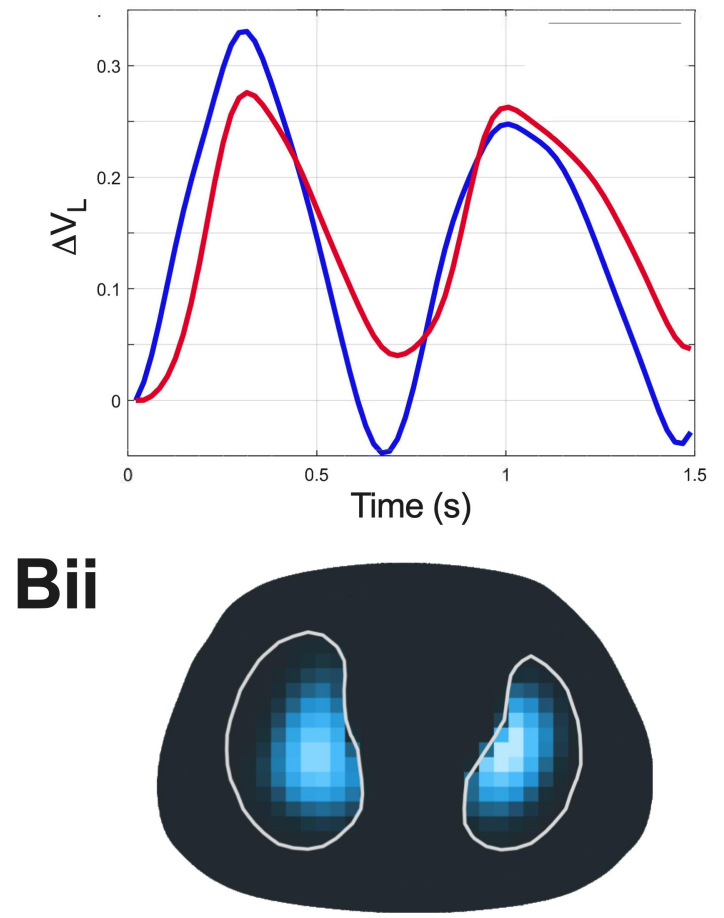

$\mathrm{Ci}$

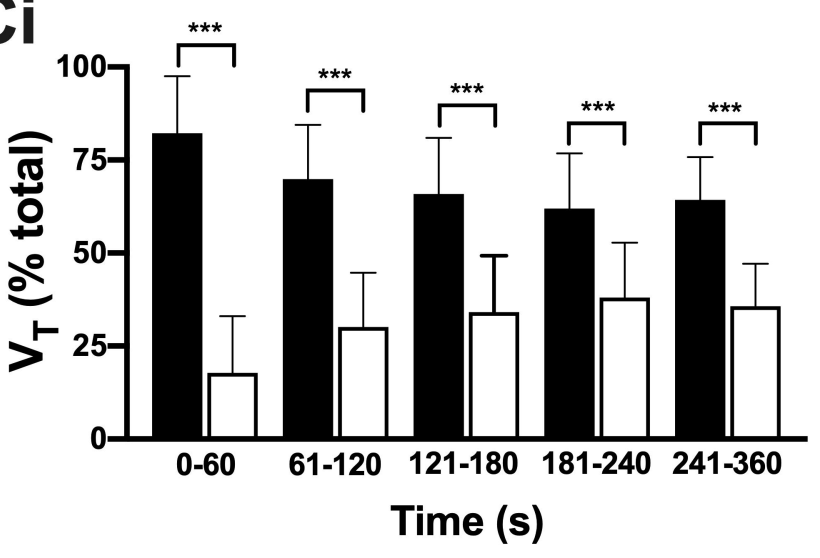

Cii

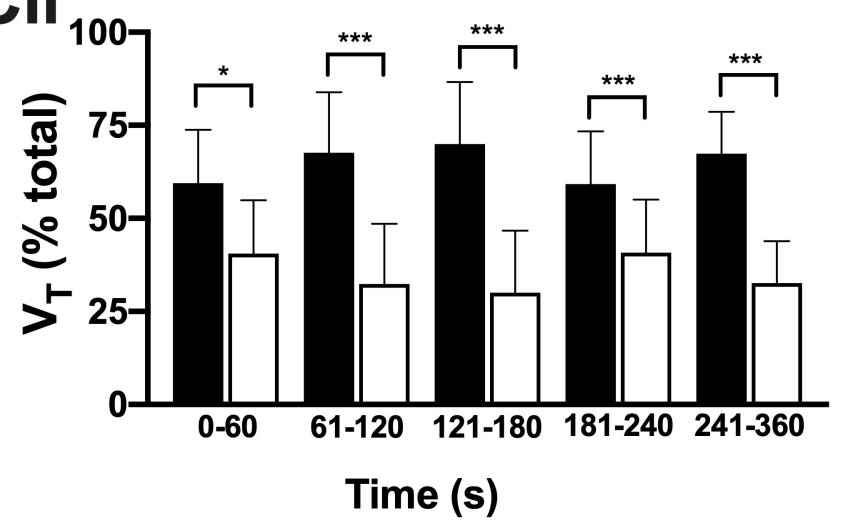

Di

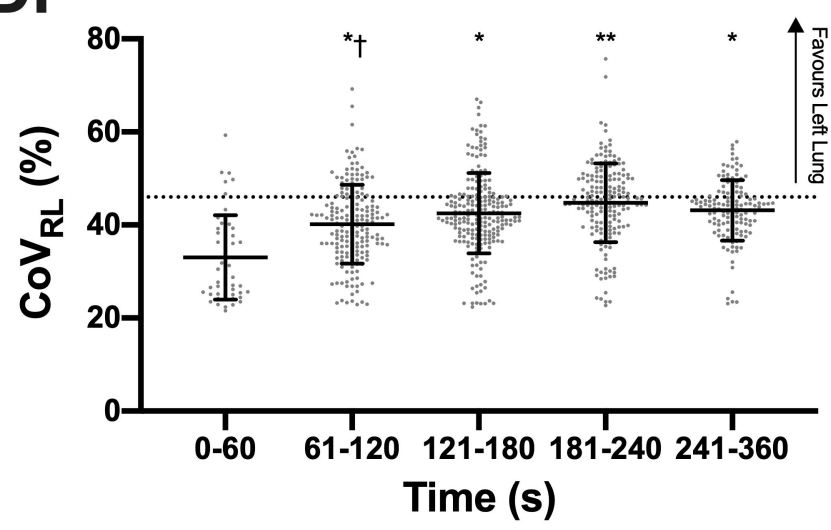

Dii

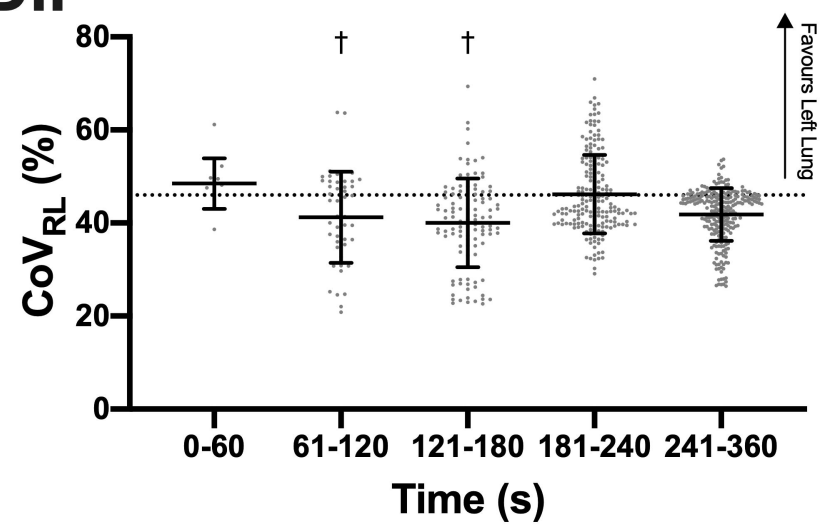




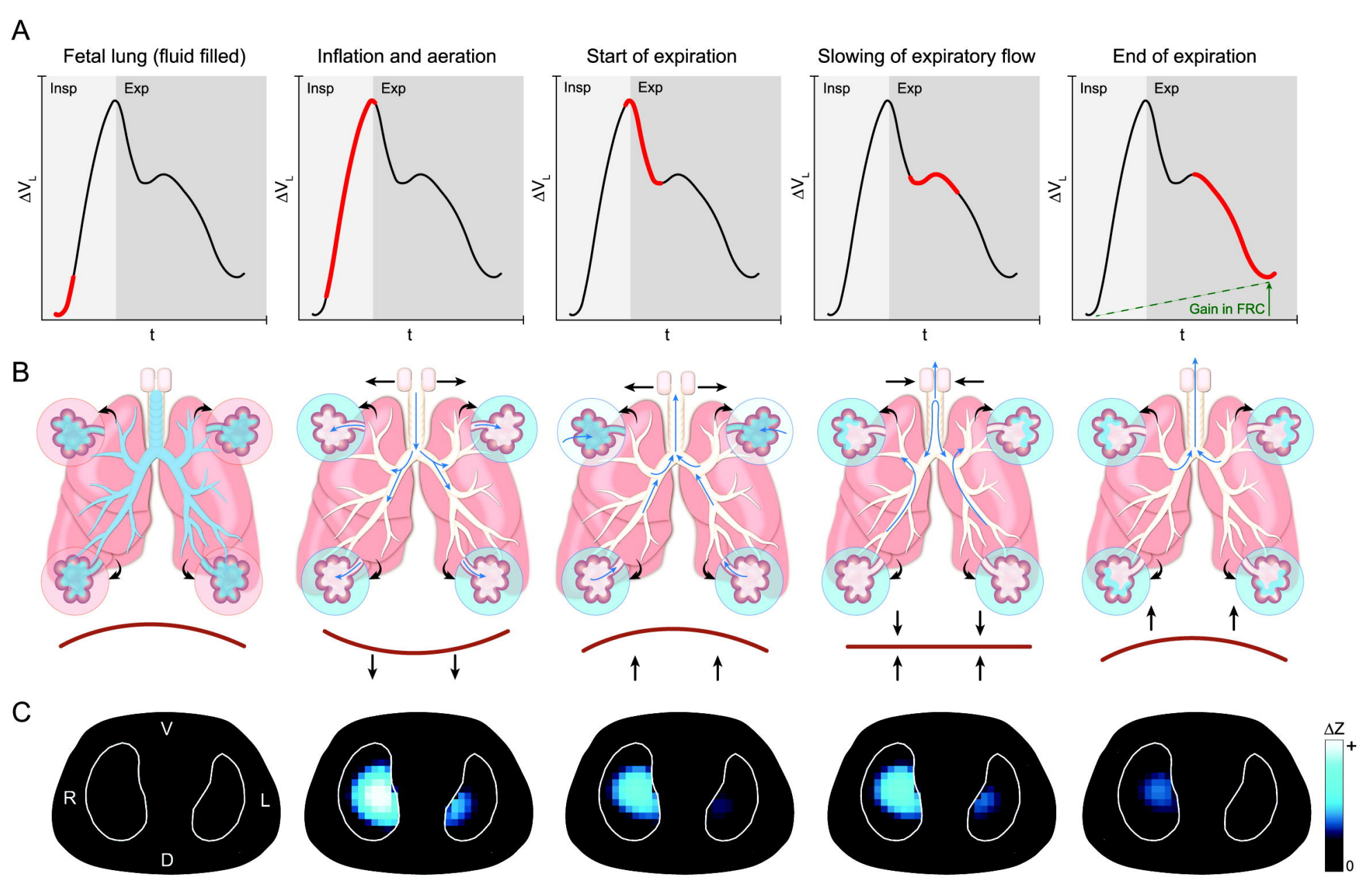

